\title{
BIOCHEMICAL COMPOSITION CHANGES OF GRAM-NEGATIVE MICROORGA- NISMS UNDER THE ACTION OF NEW CHEMICAL COMPOUNDS
}

\author{
Carolina LOZAN-TIRSU, Elena ZARICIUC \\ Nicolae Testemitanu State University of Medicine and Pharmacy, Republic of Moldova
}

Corresponding author: Carolina Lozan-Tirsu, e-mail: carolina.lozan@usmf.md

DOI: 10.38045/ohrm.2021.3.09

CZU: 579.84:577.1

Keywords: antimicrobial activity, antioxidant-enzyme activity, chemical compounds, CT, SOD.
Cuvinte cheie: activitate antimicrobiană, enzime cu activitate antioxidantă, compuși chimici, CT, SOD.
Introduction. It is known that the enzymes catalase (CT) and superoxide dismutase (SOD) are actively involved in protecting cells of microbial pathogens against the biochemical factors produced by macrophages in vivo, in order to stop infection. Therefore, this study was aimed to quantify the parameters of the antioxidant-enzyme activities within the reference cultures under the action of selected new chemical compounds.

Material and methods. Cu (II) coordination compounds, Co (II) and Zn (II) were included as "in vitro" study material, as well as aromatic propenones synthesized at the Department of Inorganic Chemistry, at State University of Moldova. The antimicrobial effects were tested on three gram-negative reference strains. The enzymatic activity of SOD and the CT activity was determined to assess the pathogen-induced changes in the antioxidant status under the action of newly tested compounds.

Results. The new chemical compounds showed a significant decrease in the antioxidant enzymatic activities of SOD and CT, induced in all reference strains used, which indicates an intense oxidative stress generated by the tested compounds.

Conclusions. The specific activity of new chemical compounds on primary antioxidant enzymes, which represent pathogenicity factors of infectious agents, allows us to assume the benefits of in vivo effect of new native substances, as well as to recommend the selected compounds for further biomedical tests.

MODIFICĂRILE CONȚINUTULUI BIOCHIMIC AL MICROORGANISMELOR GRAMNEGATIVE SUPUSE ACTIUNII COMPUȘILOR CHIMICI NOI

Introducere. Se știe că enzimele catalaza (CT) și superoxid dismutaza (SOD) se implică activ în protecția microorganismelor patogene contra factorilor biochimici, produși de macrofage in vivo pentru a stopa infecția. Prin urmare, considerăm utilă cuantificarea parametrilor ce reflectă activitatea enzimelor antioxidante în culturile de referință la acțiunea compușilor chimici nou selectați.

Material și metode. In calitate de obiecte de studiu in vitro au servit compușii coordinativi ai Cu (II): Co(II), Zn(II), dar și propenonele aromatice sintetizate la Catedra de chimie anorganică a Universitătii de Stat din Moldova. Efectele antimicrobiene au fost testate pe 3 tulpini de referință Gram-negative. A fost determinată activitatea enzimelor SOD și CT pentru a aprecia modificările statutului antioxidant al culturilor de microorganisme patogene sub influența compușilor nou testați.

Rezultate. Compușii chimici noi induc în toate culturile de referinț̆ testate o reducere semnificativă a nivelului de activitate a enzimelor antioxidante SOD și CT, ceea ce indică prezența unui stres oxidativ intens, generat de compușii testați.

Concluzii. Acțiunea specifică a compușilor chimici noi asupra enzimelor antioxidante primare, care constituie unul dintre factorii de patogenitate a agenților infecțioși, permite presupunerea unui eventual efect benefic in vivo al noilor substanțe autohtone si recomandarea compușilor selectați pentru teste biomedicale. 


\section{INTRODUCTION}

Bioinorganic chemistry is a field that studies the role of metals in biology, which has opened new avenues for scientific research of coordination compounds. A large number of compounds are regarded as being of major biological importance. Some metals are essential for biological functions, being a part of the enzymes and cofactors involved in a range of various processes (1).

The pharmacological activity of metal compounds depends on the metal ion, its ligands and the integral compound structure. These factors are responsible for the metal complexes to reach the specific target site within the body. It is known that certain metal ions enter the bacterial cells and inactivate their enzymes. Some metal ions might cause the formation of peroxide, which leads to bacterial death (2).

A series of publications have studied the particularities of action of new antimicrobial compounds, showing various biochemical composition changes in the cells of microbial pathogens subjected to toxic antimicrobial activity. It is known that the enzymes catalase (CT) and superoxide dismutase (SOD) are actively involved in protecting cells of pathogenic microorganisms against biochemical factors produced by macrophages in vivo to stop infection $(3,4,5,6)$.

Superoxide dismutase is involved in neutralizing the superoxide radical. The active synthesis and the increased activity of superoxide dismutase contributes to the microbial survival under conditions of oxidative stress. High biomass content of superoxide dismutase is a biological marker of moderate oxidative stress, whereas the decrease of enzyme activity below normal is an indicator of deep oxidative stress. Catalase activity contributes to the elimination of hydrogen peroxide formed due to both normal processes and influence of harmful factors. It has been determined that the catalase activity exhibits a significant tentime increase in case of oxidative stress in differrent cell types. Thus, an increased amount of catalase and superoxide dismutase produced by the pathogenic microorganisms help in neutralizing the hydrogen peroxide and superoxide radical of the immune cells, thereby avoiding the microbial death. The significant decrease in the activity of these two important protective factors leads to a greater vulnerability of bacteria in vivo, which might be an argument for conducting further biomedical researches to promote these valuable compounds (7).

The performed studies represent a valuable argument to select and study the particularities of action of new chemical compounds as substances that produce biochemical changes on the reference strains of pathogenic microorganisms. These studies represent an argument for conducting biomedical research in the further promotion of these valuable compounds.

\section{MATERIAL AND METHODS}

$\mathrm{Cu}$ (II) coordination compounds, Co (II) and Zn (II) were included as "in vitro" study material, as well as aromatic propenones synthesized at the Department of Inorganic Chemistry (at State University of Moldova). The antimicrobial effects were tested on 3 gram-negative reference strains, Escherichia coli ATCC 25922, Shigella sonnei ATCC 25931, Salmonella enterica (S. Abony ГИСК03/ 03). These strains derive from two culture collections recognized as material suppliers of biological quality for performance studies: American Type Culture Collection (ATCC, USA) and the State Collection of Microbial Pathogens of the State Scientific Research Institute for Standardization and Control of biological medical preparations „L. A. Tarasevici" (ГИСК, Russian Federation).

The superoxide dismutase (SOD) activity was determined based on the principle of the enzyme ability to inhibit the photochemical reduction of nitroblue tetrazolium according to the method of Giannopolitis and Ries in 1977 (8) with subsequent modifications.

The sample in the amount of $100 \mathrm{mg}$ is cold lysed with extractive buffer $(2 \mathrm{~mL}$ buffer $\mathrm{K}$, Na-phosphate, $50 \mathrm{mM}, \mathrm{pH} 7.8+20 \mu \mathrm{L}$ phenylmethylsulfonyl fluoride solution of $100 \mathrm{mM}$ ). The homogenised tube shall be passed into the Ependorf tube and centrifuged for $5 \mathrm{~min}$. at $12000 \mathrm{~g}$. The reactant mixture is prepared with the use of 100 $\mu \mathrm{l}$ bacterium extract, to which $0.5 \mathrm{~mL}$ solution of $0.05 \%$ nitroblue tetrazole, $0.9 \mathrm{ml}$ buffer $\mathrm{K}$, Naphosphate, $50 \mathrm{mM}$, pH 7.8 and $20 \mu \mathrm{L}$ solution of $0.24 \%$ EDTA. For each sample, prepare two identical working tubes as described above. One of the test tubes is placed in the dark and serves as a witness of darkness. The second test tube is exposed to light. In addition, the blank samples are pre- 
pared, of which the bacterial extract is missing which are intended to perform the calculation of the maximum amount of formazan formed. Control swabs contain instead of bacterial extract, $100 \mu \mathrm{L}$ tampom $\mathrm{K}$, Na-phosphate $50 \mathrm{mM}$ with $\mathrm{pH}$ 7.8.

The reaction is initiated by adding $20 \mu \mathrm{L}$ of $0.025 \%$ riboflavin solution (added to all test tubes included in the study). Dark-control and experience-witnessed screws shall be placed in place away from the rays of light. The other test tubes shall be placed below 2 illuminating lamps with a power of $18 \mathrm{~W}$ for $15 \mathrm{~min}$. The reaction is stopped by disconnecting the light. The optical density shall be read at the wavelength of $560 \mathrm{~nm}$ immediately after the disconnection of the light, and in case there is a time interval between disconnection and measurements, the samples shall be placed in the dark.

As a unit of activity SOD is considered the amount of enzyme, which can inhibit the reaction of reduction of nitroblue tetrazole to $50 \%$. In order to calculate the value of the optical density corresponding to a SOD activity unit, the value E corresponding to the maximum level of formation of the formazan shall be divided by 2 and shall be considered to be equal to $50 \%$ inhibition.

The calculation of the SOD activity at the mass unit shall be carried out according to the formula:

$A=(a-V-X) / m$, where $a=1-\left(E_{\text {sample }} \rho 0.5\right) /\left(E_{\text {forma- }}\right.$ zan/2) A - the activity of the SOD enzyme; $\mathrm{V}$ - volume of extract; $X$ - dilution of the extract; It's sample - the optical density measured for the sample;

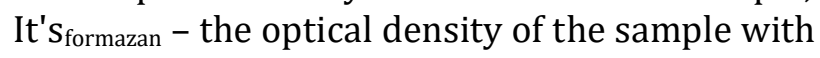
maximum formation of formazan.

The calculation can also be made in SOD activity values according to the quantitative formation index of the formazan. The following calculation formula applies to this:

$\mathrm{F}=(\Delta \mathrm{E}-\mathrm{X}) / 7.2-\mathrm{m}$, where $\mathrm{F}-$ the amount of formazan formed at the unit of mass; $\Delta \mathrm{E}$ - the difference between the optical density of the sample with the maximum formation of the forman and that of the sample to be investigated; $\mathrm{X}$ - dilution of bacterial extract; 7.2 - the value of the extinction coefficient of the forman at the wavelength of 560 $\mathrm{nm}$, in $\mathrm{mM}^{-1} \mathrm{~cm}^{-1} ; \mathrm{m}$ - the absolutely dry mass of the sample.

The catalase (CT) was determined via the spectrophotometric method proposed by Aebi in
1984. This method is aimed to determine the rate of decomposition of hydrogen peroxide by the catalase contained in the sample, which subsequently yields water and oxygen (9).

The sample in the amount of $100 \mathrm{mg}$ is cold lysed with extractive buffer $(2 \mathrm{~mL}$ buffer K, Na-phosphate, $50 \mathrm{mM}$, pH $7.8+20 \mu \mathrm{l}$ phenylmethyl-sulfonyl fluoride solution of $100 \mathrm{mM}$ ). The homogenised tube shall be passed into the Ependorf tube and centrifuged for $5 \mathrm{~min}$. at $12000 \mathrm{~g}$. The reactant mixture is prepared by adding $2.95 \mathrm{ml}$ of 0.6 $\mathrm{M}$ hydrogen peroxide to the sample $(30 \mu \mathrm{l})$. The control sample is prepared analogously, but does not contain hydrogen peroxide. Ultraviolet sample spectrophotometry is performed at $240 \mathrm{~nm}$ with an interval of $100 \mathrm{~s}$.

Calculation of catalase activity per gram of dry matter is done according to the formula:

$A=(2.3 t-\lg (E 1 / E 2))-X) / m$, where: $A$ - the activity of catalase in conventional units per $g$ of dry matter; E1 and E2 - the value of the initial optical density and above $100 \mathrm{~s}, \mathrm{X}$ - the dilution of the sample; $t$ - reaction time; $m$ - mass of the sample.

\section{RESULTS}

The activity of SOD and CT enzymes was determined to assess changes in the antioxidant status of microbial pathogenic strains under the influence of newly tested compounds.

The study results reflecting the activities of the antioxidant enzymes SOD and CT on the reference Shigella sonnei ATCC 25931 strain, when treated with new chemical compounds are presented in Figure 1.

When treated with furacillin, there was a decrease with $41.4 \%$ in catalase activity and with $50.0 \%$ in superoxide dismutase activity, compared to their activity in biomass of Shigella sonnei under normal conditions. Under the action of new chemical compounds, the SOD activity in culture accounted for $17.9-48.7 \%$ of the normal pathogenic activity. The catalase activity was $19.5-44.8 \%$ of the typical activity in the intact culture. The values of the primary antioxidant enzyme activity in the cell lysate, obtained from the culture treated with furacillin and with MIC of the selected new chemical compounds, confirm the high-intensity oxidative stress within the culture of Shigella sonnei ATCC 25931 when treated with new antibacterial chemical compounds. 


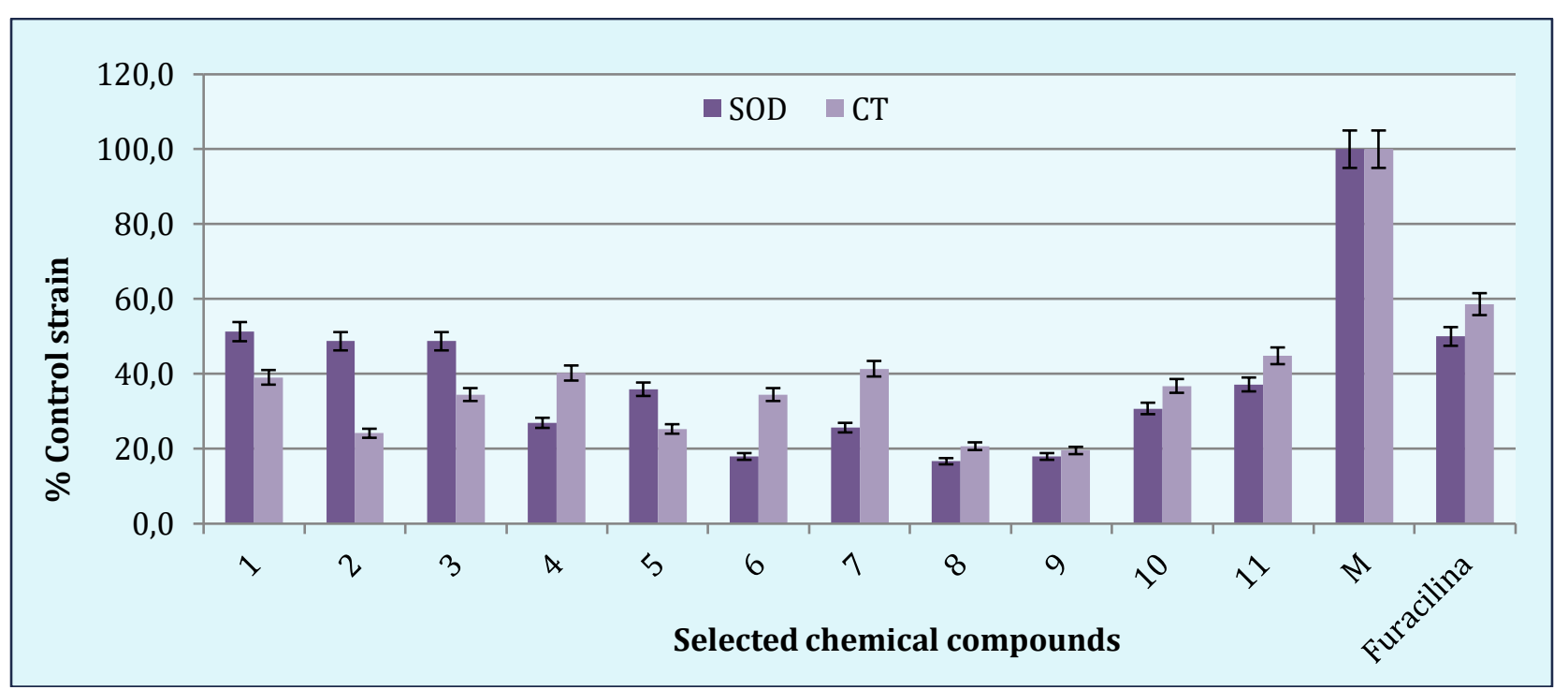

Figure 1. Changes in the antioxidant enzyme activity in the standard Shigella sonnei ATCC 25931 strain under the action of new chemical compounds: $1-\mathrm{C}_{38} \mathrm{H}_{38} \mathrm{Cu}_{2} \mathrm{~N}_{14} \mathrm{O}_{10} \mathrm{~S}_{4}$;

2 - $\mathrm{C}_{42} \mathrm{H}_{42} \mathrm{Cu}_{2} \mathrm{~N}_{14} \mathrm{O}_{12} \mathrm{~S}_{4} ; 3-\mathrm{C}_{44} \mathrm{H}_{40} \mathrm{Cl}_{2} \mathrm{Cu}_{2} \mathrm{~N}_{14} \mathrm{O}_{4} \mathrm{~S}_{6} ; 4-\mathrm{C}_{15} \mathrm{H}_{19} \mathrm{ClCuN}_{4} \mathrm{O}_{2} \mathrm{~S} ; 5-\mathrm{C}_{15} \mathrm{H}_{19} \mathrm{CuN}_{5} \mathrm{O}_{5} \mathrm{~S}$; $6-\mathrm{C}_{15} \mathrm{H}_{17} \mathrm{ClCuN}_{4} \mathrm{OS} ; 7-\mathrm{C}_{15} \mathrm{H}_{19} \mathrm{CuN}_{5} \mathrm{O}_{5} \mathrm{~S}(2,5) ; 8-\mathrm{C}_{15} \mathrm{H}_{19} \mathrm{CuN}_{5} \mathrm{O}_{5} \mathrm{~S}(3,4)$;

$9-\mathrm{C}_{15} \mathrm{H}_{19} \mathrm{CuN}_{5} \mathrm{O}_{5} \mathrm{~S}(2,4) ; 10-\mathrm{C}_{18} \mathrm{H}_{22} \mathrm{Cl}_{2} \mathrm{Cu}_{2} \mathrm{~N}_{8} \mathrm{~S}_{2} ; 11-\mathrm{C}_{9} \mathrm{H}_{11} \mathrm{ClCuN}_{4} \mathrm{~S} ; \mathrm{M}$ - untreated culture.

Two chemical are particularly highlighted, namely di $(\mu-S)$-bis \{nitrate- [2-picolidene-4(3,4-dimethylphenyl) thiosemicarbazido- (1-)] copper\} tetrahydrate and di $(\mu-S)$-bis \{nitrate [2-picolidene-4- (2,4-dimethylphenyl) thiosemicarbazido - (1-)] copper\} tetrahydrate, which exhibited the most significant reduction in both SOD and CT activities. The values obtained by treating the pathogenic strains with these two compounds were 5 times lower than the antioxidant enzyme activity in the lysate of the control culture.

The study results reflecting the activity of the antioxidant enzymes SOD and CT on the reference culture Escherichia coli ATCC 25922 when treated with new chemical compounds are presented in Figure 2.

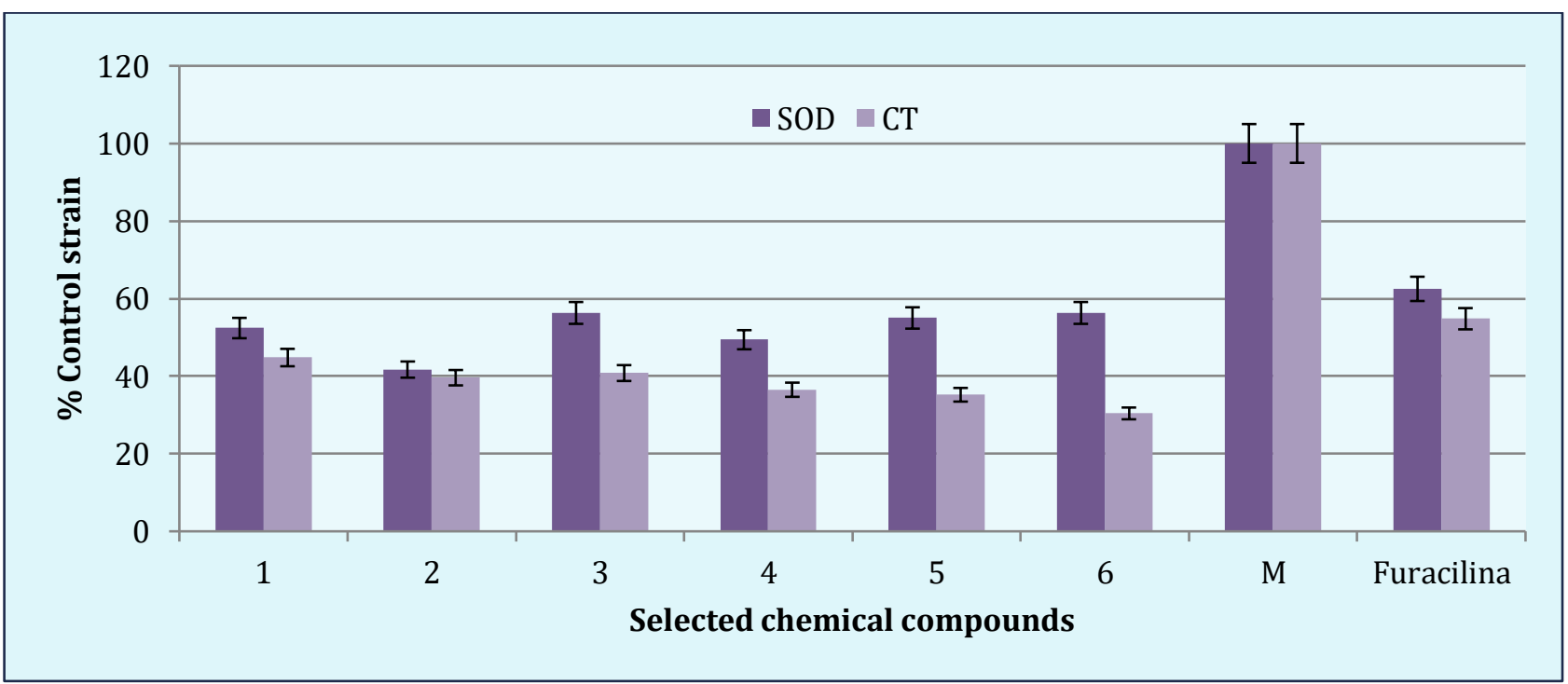

Figure 2. Changes in the antioxidant enzyme activity in the standard Escherichia coli ATCC 25922 strain under the action of new chemical compounds: $1-\mathrm{C}_{38} \mathrm{H}_{38} \mathrm{Cu}_{2} \mathrm{~N}_{14} \mathrm{O}_{10} \mathrm{~S}_{4}$; $2-\mathrm{C}_{44} \mathrm{H}_{40} \mathrm{Cl}_{2} \mathrm{Cu}_{2} \mathrm{~N}_{14} \mathrm{O}_{4} \mathrm{~S}_{6} ; 3-\mathrm{C}_{46} \mathrm{H}_{46} \mathrm{Cu}_{2} \mathrm{~N}_{18} \mathrm{O}_{10} \mathrm{~S}_{6} ; 4-\mathrm{C}_{46} \mathrm{H}_{42} \mathrm{Cu}_{2} \mathrm{~N}_{18} \mathrm{O}_{10} \mathrm{~S}_{4}$; $5-\mathrm{C}_{18} \mathrm{H}_{22} \mathrm{Cl}_{2} \mathrm{Cu}_{2} \mathrm{~N}_{8} \mathrm{~S}_{2} ; 6-\mathrm{C}_{9} \mathrm{H}_{11} \mathrm{ClCuN}_{4} \mathrm{~S} ; \mathrm{M}$ - untreated culture. 
Under the action of furacillin, there was a $45.2 \%$ and a $37.5 \%$ reduction in catalase and superoxide dismutase activities, respectively, compared to the activity of CT in Escherichia coli biomass obtai-ned under normal conditions. The SOD activity accounted for $41.7-56.3 \%$ of the reference $E$. coli SOD activity, when treated with new chemical compounds, thus showing a statistically significant difference $(\mathrm{p}<0.01)$. The catalase activity exhibited lower values, being $30.4-44.8 \%$ of the typical activity in intact culture. As in the case of SOD, the statistically significant differences between the enzyme activity in the control biomass and in the biomass treated with furacillin or the selected compounds were at the same level of significance. The obtained results confirmed a high-intensity oxidative stress in the Escherichia coli ATCC 25922 strain under the action of new antibacterial chemical compounds. As regarding the reference culture, we cannot highlight any of the six selected compounds, since their action on the antioxidant enzyme activity was very similar from case to case.

The study results reflecting the activity of the antioxidant enzymes SOD and CT on the reference culture Salmonella enterica (S. Abony ГИСК 03/03 y) under the action of new chemical compounds are presented in Figure 3.

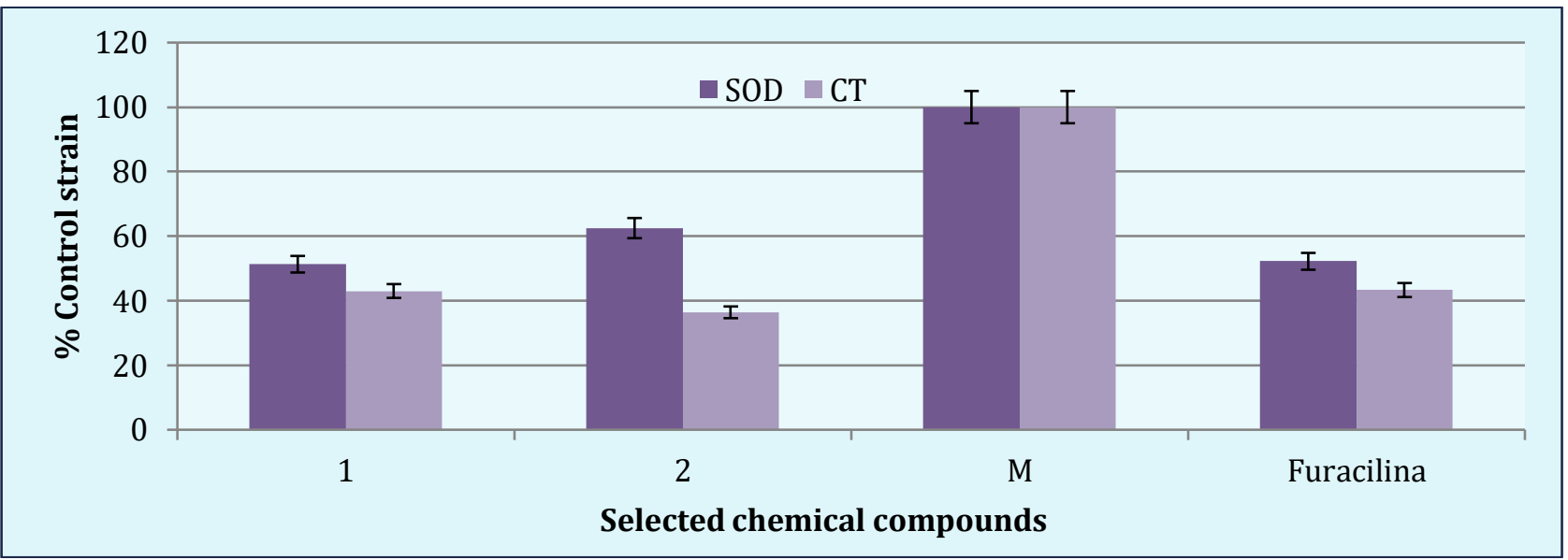

Figure 3. Changes in the antioxidant enzyme activity in the standard Salmonella enterica

(S. Abony ГИСК 03/03y) strain when treated with new chemical compounds: 1 - $\mathrm{C}_{38} \mathrm{H}_{38} \mathrm{Cu}_{2} \mathrm{~N}_{14} \mathrm{O}_{10} \mathrm{~S}_{4} ; 2-\mathrm{C}_{44} \mathrm{H}_{40} \mathrm{Cl}_{2} \mathrm{Cu}_{2} \mathrm{~N}_{14} \mathrm{O}_{4} \mathrm{~S}_{6} ; \mathrm{M}$ - untreated culture.

Under the action of furacillin, there was a decrease to $56.7 \%$ in catalase and to $47.8 \%$ in superoxide dismutase activities, compared to the CT and SOD in Salmonella biomass obtained under normal conditions. The SOD activity accounted for $51.3 \%$ and $62.5 \%$ of the normal activity of salmonella strain under the action of new chemical compounds. The catalase activity level was $36.4 \%$ and $43.0 \%$, which was lower than the typical activity level in intact culture. These fluctuations confirmed the high-intensity oxidative stress for the culture of Salmonella enterica (S. Abony ГИСК 03/03 y) under the action of new antibacterial chemical compounds.

\section{DISCUSSIONS}

Under the action of new chemical compounds, all the reference cultures tested, showed a significant reduction in the activity of the antioxidant enzymes superoxide dismutase and catalase, which indicated an intense oxidative stress gen erated by the tested compounds.

The same phenomenon was observed when treating the microbial pathogens with furacillin. This substance is known for its antibacterial mechanism that consists in the formation of amino derivatives due to the reduction of nitrofural 5-nitrogroup under the action of bacterial flavonoid activity. The amine derivatives formed, conformationally alter the proteins and eventually lead to cell death.

Since there is a decrease in the activity of both catalase and superoxide dismutase, we can assume the alteration of the specific conformation of the proteins, including the above- mentioned enzymes. However, further research is required to confirm this assumption.

Hence, the new antibacterial compounds used on 
microbial pathogenic strains, produce an oxide tive stress within these microorganisms, being associated with the accumulation of free radicals, lower total antioxidant capacity, a reduced expression and protective antioxidant enzymes activity.

\section{CONCLUSIONS}

1. One of the mechanisms of action of the newly tested compounds is based on the significant decrease in the activity of first-line antioxidant enzymes superoxide dismutase and catalase. Thus, under the action of new chemical compounds the activity of these two enzymes decreased below $30 \%$ of their activity in untreated biomass.

2. Hence, we might assume the preserving of the antibacterial effect observed in vivo, whereas the enzymes are regarded as the key elements in the protection of microbial pathogens against the activity of the host immune system.

3. The specific action of new chemical compounds on primary antioxidant enzymes, which is one of the pathogenicity factors of infectious agents, allows assuming the beneficial in vivo effect of new native substances and recommending these selected compounds for further biomedical tests.

\section{CONFLICT OF INTERESTS}

Nothing to declare.

\section{REFERENCES}

1. Iațco IU. Tehnologii de obţinere a preparatelor lipidice din biomasa algei verzi Dunaliella salina. Autoref. tezei de dr. șt. biologice. Chișinău, 2012.

2. Rizzotto M. Metal Complexes as Antimicrobial Agents. In: A search for antibacterial agents. Tech. 2012;73-88.

3. Gulya AP, Lozan-Tyrshu KS, Tsapkov VI, Chumakov YUM, Zhanno E, Rudik VF. Synthesis, structure, and microbial activity of copper (II) chelates containg imidazole and condensation products of $\alpha$-amino acids with Salicylaldehyde and its derivates. Russian Journal of General Chemistry. 2013;83(3):530-537.

4. Gulya AP, Lozan-Tyrshu KS, Korzha ID, Rudik VF. Coordination compounds of Copper with 2-Formiylpyridine 4 - (Dymethylphenyl)thiosemicarbazones. Russian Journal of General Chemistry. 2012;82(11):1869-1872.

5. Gulea A, Usataia I, Graur V, Chumakov Yu, Petrenko P, Balan G, et al. Synthesis, Structure and Biological Activity of Coordination

Date of receipt of the manuscript: 08/04/2021

Date of acceptance for publication: 16/06/2021

Carolina LOZAN-TIRSU, ORCID ID: 0000-0003-3831-2758 Elena ZARICIUC, ORCID ID: 0000-0002-6966-218X
Compounds of Copper, Nickel, Cobalt, and Iron with Ethyl N'-(2-Hydroxybenzylidene)N-prop-2-en-1-ylcarbamohydra- zonothioate. Russian Journal of General Chemistry. 2020;90(4):630-639.

6. Munna MS, et al. Influence of exogenous oxidative stress on Escherichia coli cell growth, viability and morphology. Am J Bioscience. 2013;1:59-62.

7. Romero DM, Rios De Molina MC, Juarez AB. Oxidative stress induced by a commercial glyphosate formulation in a tolerant strain of Chlorella kessleri. Ecotoxicology and Environmental Safety. 2011;74:741-747.

8. Giannopolitis CN, Ries SK. Superoxide dismutase I. Occurence in higher plants. Plant Physiol. 1972;59:309-314.

9. Aebi H. Catalase in vitro. Methods Enzimol. v.105, 1984.

10. Lozan-Tîrşu C. Alterations of total antioxidant capacity of pathogen cultures under the influence of novel chemical compounds. One Health and Risk Management. 2020;2:50-57. 